\title{
Effects of Internal Marketing on Customer Orientation Behaviour of Selected Hotels' Employees in Nigeria
}

\author{
Dr. Nebo, Gerald Nwora \\ Department of Marketing, \\ Enugu State University of Science and Technology, Enugu State, Nigeria \\ Dr. Okechukwu, Elizabeth Uzoamaka \\ Department of Business Administration, \\ Enugu State University of Science and Technology, Enugu State, Nigeria \\ doi: 10.19044/esj.2017.v13n16p212 URL:http://dx.doi.org/10.19044/esj.2017.v13n16p212
}

\begin{abstract}
This study was carried out to determine the Influence of Internal Marketing on Customer Orientation Behaviour of Hotel Employees in Nigeria. The objectives of the study include: to determine the effect of internal marketing on customer orientation behaviour of hotel employees; to investigate the moderating influence of personality on the relationship between internal marketing and customer orientation behaviour of the hotel employees; and to investigate the moderating influence of job satisfaction on the relationship between internal marketing and customer orientation behaviour of the hotels' employees. Survey research design method was adopted for the study. 83 and 174 hotel managers and employees respectively were selected for the study from 20 hotels operating in different geo-political zones of Nigeria. Questionnaire was used for collection of data. Convenience sampling method was used for selecting both the hotels' managers and guest service employees used for the study. The hypotheses were tested using multiple linear regression. It was revealed that internal marketing has significant influence on customer orientation behavior of hotels' employees; personality significantly moderates the relationship between internal marketing and customer orientation behavior of the hotel employees; and job satisfaction significantly moderates the relationship between internal marketing and customer orientation behavior of the hotels' employees. It was recommended that hotel managers should give much priority to internal marketing practice while controlling for the personality and job satisfaction of the guest service employees.
\end{abstract}


Keywords: Internal Marketing, Customer Orientation, Personality, Job Satisfaction, Hotel Employees

\section{Introduction}

The hotel industry plays a significant role in the economic development of Nigeria. Apart from its significant contributions to the nation's GDP, the industry provides gainful employment for hundreds and thousands of Nigerians through the network of hotels and their branches spread across the country. In some big cities in Nigeria such as Lagos, Abuja, Port Harcourt, Enugu and Benin, hotels of different qualities are seen in notable streets and more are being opened on yearly basis. Due to the increasing need for people to travel for pleasure, visit friends, take vacations, have a good time, participate in a conference, convention or workshop outside their homes; hotel industry in Nigeria is expected to grow even more.

Hotels is a service-oriented and very competitive industry that depend heavily on clients' services and customer satisfaction for survival. The success or failure of the industry in Nigeria revolves around its customers. One of the biggest contemporary challenges of management in hotel industry in Nigeria is to provide and maintain customer satisfaction which according to researcher scholars lead to customer loyalty, repeat purchases, patronage and organizational profits. In the past, marketing scholars have been advocating the adoption of marketing mix variables popularly known in marketing literature as 7P's (product, price, promotion, place, people, physical evidence and process) for attracting and retaining customers' patronage especially to service firms. However, the emphasis has shifted to the adoption of internal marketing as a strong tool for customer attraction since it was first introduced forty-one years ago by Berry et al (1976).

Internal marketing advocates that competitive service industry can only achieve customer satisfaction and sustainability by hiring, training and rewarding service employees that are willing and able to deliver quality service in customer-oriented ways. Awwade and Agti (2011) describe customer orientation as the employees' ability to meet customer needs as well as the extent to which they enjoy doing it. Internal marketing is based on the notion that employees of an organisation should be handled as internal customers and should be presented as internal products that satisfy the needs and desires of external customers (Berry et al, 1976). Vrontis et al (2010 content that in the service delivery such as hotels; front line employees must be empowered to some degree in order to cope with customers' special demands. The very essence of internal marketing is that satisfied employees make satisfied customers. Empirical studies in the service sector support internal marketing as having a link with employees' job satisfaction which in 
turn influences the value of services provided to the customers (Vrontis et al, 2010). This assertion led to investigating the effects of internal marketing on employees’ customer orientation in hotel industry in Nigeria.

\section{Statement of the Problem}

In the present day Nigeria, firms in the hotel industry are in intense competition such that getting enough customers to offset business costs is a big challenge. In spite of the keen competition among firms in the hotel industry, the customer satisfying orientation of some of the employees who deal directly with the customers tend to be questionable sometimes; yet the behaviour of these employees in the service industry have been described by academic scholars as key to customers' satisfaction. Surprisingly, customers' needs in some of these hotels appear to be taken for granted by the so called frontline service employees even in the face of tight competition. Some of the employees appear unfriendly, impolite, undependable, untrustworthy, fraudulent, unsympathetic, repulsive, uncommitted to their jobs and sometimes too busy to respond promptly to customers’ queries.

The challenge for most hotel managers in Nigeria is how to improve the behaviours of the service employees in order to serve customers' better. Increasingly, most contemporary literature and studies on organizational marketing have argued very strongly on the application of internal marketing program as one of the best ways to achieve employees' job commitment and customer orientation in an organization (Yusuf et al, 2014 and Farhad et al, 2013). However these studies were done in other industries and in other countries other than the hotel industry in Nigeria. Even among the scholars that have conducted this study; inconsistences exist in their findings. For example, Dalvi and Vahidi (2013) and Oakley and Carolina (2012) studies show that internal marketing has significant influence on customer orientation behaviour. In contrast, Yusuf et al's (2014) study show that internal marketing has a significant effect on both organizational commitment and customer orientation. Other studies show the likelihood for some intervening variables such as job commitments, personality and job satisfaction to affect the relationship between internal marketing and customer orientation behaviour of employees (Bellaouaied and Gam, 2012). From the above scenario, it can be deduced that inconsistencies found in the results of the previous research studies are wide and few research efforts in this area have been made in the hotel industry in the Nigerian context. This apparent knowledge gap observed in the literature triggered the need for this study.

\section{Objectives of the Study}

The following objectives were sought in this study: 
(i) To determine effects of internal marketing on customer orientation behavior of the hotel employees in Nigeria

(ii) To investigate moderating influence of personality on the relationship between internal marketing and customer orientation behaviour of hotel employees in Nigeria

(iii) To investigate moderating influence of job satisfaction on the relationship between internal marketing and customer orientation behaviour of the hotel employees in Nigeria

\section{Research Hypotheses}

The following hypotheses were formulated to guide the study:

(i) $\mathrm{H}_{01}$ : Internal marketing does not have significant influence on the customer orientation behavior of hotel employees in Nigeria

(ii) $\mathrm{H}_{02}$ : Personality does not significantly moderate the relationship between internal

marketing and customer orientation behavior of the hotel employees in Nigeria

(iii) $\mathrm{Ho}_{3}:$ Job satisfaction does not significantly moderate the relationship between internal

marketing and customer orientation behavior of the hotel'employees in Nigeria

\section{Review of the Related Literature}

This section takes a look at the conceptual framework of this study which is the various variables studied, their dimensions and measures. Three groups of variables were used in the study viz: independent (predictor) variable, dependent (criterion) variable and moderating (contextual) variable. Independent or predictor variable is internal marketing, dependent or criterion variable is customer orientation behaviour while moderating variables are personality and job satisfaction. Each of them is described below..

\section{Internal Marketing}

Internal marketing concept was first made known in service marketing literature by Berry et al (1976). Thereafter, for the past several years, researchers have been studying the concept of internal marketing (Ruizalba et al., 2014). Today, internal marketing has come to attract attention and become more broadened on the realization that services offered by employees in an organization are the key differentiating factor that enables organizations to obtain a competitive advantage. It has also become one of the best marketing practices known to improve service orientations and organizational management (Greene et al, 1994). 
The overall implication of internal marketing is that, when an employee is satisfied by his organization, he is most likely to deliver quality service to the external customers (Ogunnaike et al., 2012). The goal of internal marketing actually is to make employees as important as the external customers by treating them as internal customers. Lings and Greenley (2005) advocate that the goal of internal marketing lies in motivating the employees and encouraging them to offer superior services to customers which will improve the customers' satisfaction of the company services.

Greene et al (1994) define internal marketing as the promotion of the firm and its product(s) to the firm's employees, and for this strategy to be successful top level management must fully embrace it. Internal marketing means applying the philosophy and practices of marketing to the people who serve the external customer so that the best possible people can be employed and retained and they will do the best work possible. More specifically, internal marketing is all about viewing employees as internal customers, jobs as internal products, and endeavoring to design these products to meet the needs of external customers better.

\section{Components or measures of Effective Internal Marketing}

As regards what actually constitutes internal marketing, its functions and who is supposed to carry out the function, according to Rafiq and Ahmed (2000), there is a great deal of confusion in literature as there are varieties of interpretations by authors as to what actually constitutes internal marketing. These varieties had led to a diverse range of activities being grouped under the umbrella of internal marketing. Broady-Preston and Steel (2002), for example, deconstructed internal marketing into recruiting; training, developing and motivating staff, thus they believed it is the external marketing impact of each member of the staff that is the essential focus of an internal marketing strategy. Ha et al. (2007), identified 12 constructs of internal marketing which include: inter-functional coordination and integration, customer orientation, marketing-like approach, job satisfaction, empowerment, and employee motivation, quality of service, employee development, and vision of the organization, strategic reward, internal communication and senior leadership. Similarly, Bansal et al (2001) identify the main elements of internal marketing as employment or job security, extensive training, salary and pay, sharing of information, employee empowerment and reduction of employee status distinctions.

In the contemporary world, Martel (2012) identified internal marketing components or practices as including - training and development; reward and recognition; internal communication and empowerment. Although, many constructs have been identified by different research scholars as the constituents of internal marketing, the last four factors 
advocated by Martel (2012) seem consistent and these were investigated in this current study.

\section{Customer Orientation Behaviour}

Customer Orientation has been widely used in most strategic human resources management literature (Hennig-Thurau and Thurau, 2003) as well as in many customer satisfaction studies ( Dunn and Dahl, 2012; Oakley and Carolina, 2012). The concept refers mainly to the marketing principle that addresses the significance of considering customer needs and wishes throughout the organization (Ruizalba et al., 2014). Customer orientation is ordinarily the principle of readiness to meet and respond promptly to customers' needs and wants (Awwad and Agti, 2011). In fact, it is the total packages of external customers' welfare in an organization. When a customer orientation approach is taken, there is likelihood of higher performance and quality delivery services by employees (Brady and Cronin, 2001).The earliest advances on the topic examined the overall customer orientation of entire organizations, usually referred to as market orientation (Ruizalba et al., 2014). Academic researchers and scholars have hence, defined the concept of customer orientation as 'the set of behaviors and beliefs that places a priority on customers' interests and continuously creates superior customer value' (Awwad and Agti, 2011). Most customer-oriented firms would 'stay close to the customers', as a means of identifying, understanding and monitoring their needs. Thus, understanding the needs of customers requires strong market sensing and customer-relating capabilities (Kirca et al., 2005). Customer-oriented firms foster direct customer contact, rely on focus groups and customer surveys to collect information about customer desires and perceptions of current products and services, and use customer-supplied information to design and deliver products and services. Furthermore, customer-oriented firms attempt to develop close relationships with customers to gain greater insights of their needs (Kirca et al., 2005).

Moreover, for a company to be customer oriented, their employees too must be customer oriented (Neill and Richard, 2012; Stock and Watson, 2003). The definition of employee customer orientation usually falls into one of two perspectives: one focuses on the attitudes and beliefs of the employees, and the other focuses on actual behavior (Stock and Watson, 2003). By considering the attitudinal and belief perspective, Brady and Cronin, 2001), described customer orientation as an employee's tendency or predisposition to meet customers' needs in the job context. Other researchers also present customer orientation as a belief (Kirca et al., 2005) or value (Wieseke et al., 2007) held by an employee concerning the importance of satisfying customer needs. 


\section{Measures of Employee Customer Orientation}

Customer orientation is widely acclaimed to consist of both 'attitudinal' and 'behavioural' dispositions of the employees toward helping customers in making their purchasing choices and decisions. Through this service assistance, the employees help their firm to satisfy the customers' long-term needs (Awwade and Agti, 2011). The attitude and behaviour disposed by the employees determine largely their orientation toward the customers.

Customer orientation behaviour is demonstrated by a series of customer service activities carried out by employees (usually the frontline employees) to enhance the level of customer satisfaction. Substantively therefore, an employee that is customer oriented can be described through his/her behavioural intentions and readiness to carry out customer services activities satisfactorily. In support of this assertion, Saxe and Weitz (2010) describe a customer oriented employee as one who is committed to behaviors which lead to the long-term satisfaction of the customers rather than shortterm self-interest.

To idealize the basic components of such behavior and attitudes, Saxe and Weitz (2010) opinionate that, customer orientation is made up of seven components: (1) a desire to help customers make satisfactory purchase decisions, (2) helping customers assess their needs, (3) offering products that will satisfy those needs, (4) describing products accurately, (5) adapting sales presentations to match customer interests, (6) avoiding deceptive or manipulative influence tactics, and (7) avoiding the use of high pressure. This study concentrated on these seven measures of customer orientation behaviour as they relate to hotel employees in Nigeria.

\section{Personality and Job Satisfaction as Moderating Variables Personality Factors}

Personality in the field of psychology refers to those factors that describe the true nature of a person using some traits as distinct from other persons. It refers basically to human nature or character. Although various scholars have advanced different personality traits likely to affect employees' customer orientation such as empathy, ego strength, selfconfidence, habit of industry, enthusiasm, maturity, creativity, aggressiveness, responsibility (Dunn and Dahl, 2012), this study concentrates on the five big personality factors identified by Bartone et al (2009) and consistently mentioned in the literature by other scholars as exerting significant influence on job behaviour. These include: Neuroticism, Extroversion, Openness, Agreeableness and Conscientiousness. 


\section{Job Satisfaction}

The concept of job satisfaction is multifaceted in nature consisting of several definitive meanings from different notions. Some management and human resource authors used intrinsic and extrinsic distinctions to conceptualize job satisfaction (Jenaibi, 2010). Some used certain facets of the job to idealize job satisfaction (Tsui et al., 2007), while others used total satisfaction derived from the job (Jenaibi, 2010). From the aspects of the job perspective, Churchill et al (1997) describe job satisfaction as all the characteristics an employee find rewarding, fulfilling and satisfying or frustrating and unsatisfying. It means the combination of positive or negative feelings that workers have towards their tasks. From the total satisfaction perspective, Bover (2004) describe job satisfaction as a measure of the difference between what an employee expects from the job and what he/she actually gets. It is a function of employee's expectation and employee's experience. The narrower the two (expected and actual experience) concepts the more an employee is satisfied. However, a wide gap between the two is an indicator of job dissatisfaction. According to Churchill et al (1997), measures of job satisfaction are seven and these include: satisfaction with pay/salary package, promotion opportunities, relationship with co-workers, relationship with supervisors, nature and content of the job itself, company policies and support as well as behaviour of the customers. However, this study investigated the first five job satisfaction measures advanced by Churchill et al (1997).

\section{Empirical Studies}

Research in the service sector show that internal marketing has significant influence on internal customers (employees) which in turn influences their customer orientation behaviour and organizational profits (Bellaouaied and Gam, 2012; Dalvi and Vahidi, 2013; Yusuf et al 2014). In the relationship between internal marketing and job satisfaction, Rafiq and Ahmed's (2000) study indicated that internal marketing positively influences employees' job satisfaction. In the relationship between job satisfaction and customer orientation behaviour past studies proved that there is a positive relationship between employees' job satisfaction and job performance including quality of customer-oriented service (Churchill et al, 1997 and Jenaibi, 2010)

\section{A Synthesized Conceptual Model Guiding the Study}

In the previous section, we idealized the concept of internal marketing as well as the variables (job satisfaction and personality) believed to moderate the relationship between predictor and dependent variables. We also examined some empirical studies relating to this study, which show the 
findings of previous scholars on the relationships between and/or among these variables. In this section, we present a synthesized conceptual model or framework in a pictorial form (see figure 2.1 below) uniting these basic concepts/variables. The conceptual framework in figure 2.1 served as a guide for this current study.

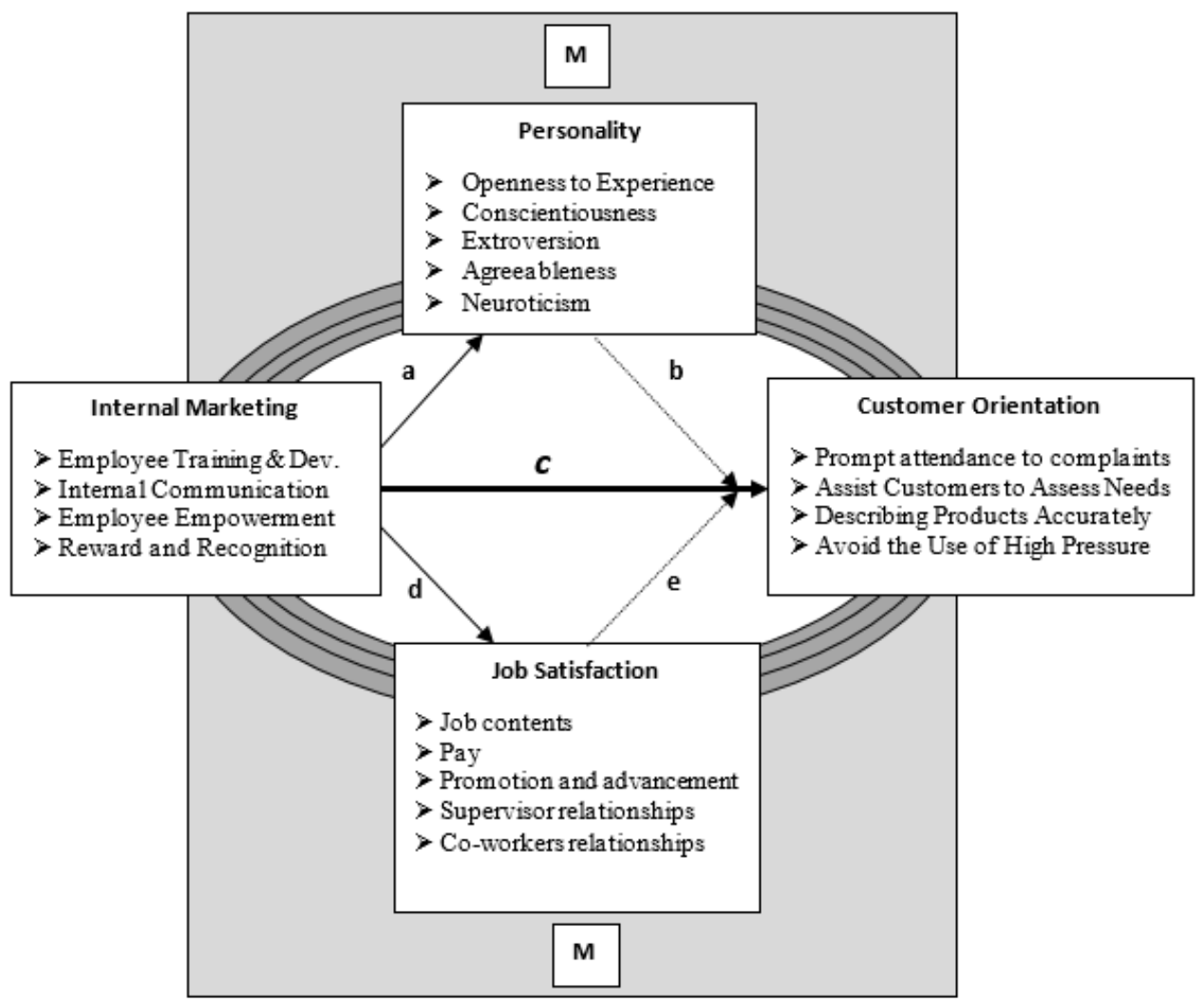

Fig. 2.1: Conceptual Framework

Source: Researcher's Illustration

Figure 2.1 above shows the hypothesized causal relationship existing among the variables studied. While this study was mainly targeted at investigating the influence of internal marketing on customer orientation behaviour of hotel employees [i.e. 'c' on fig. 2.1], it has also become evident from the literature that there could be some intervening variables which may mediate the extent to which internal marketing influence the employees' customer orientation. Such intervening variables include - personality and job satisfaction. 'a' has been hypothesized with a preconceived notion that internal marketing can positively influence personality of the employees while ' $\mathbf{b}$ ' has been hypothesized with a preconceived notion that personality can influence customer orientation behaviour of the hotel employees. 
In the same way, 'd' has been hypothesized with a preconceived notion that internal marketing could positively influence the hotel employees' job satisfaction while 'e' has been hypothesized with a preconceived notion that job satisfaction can influence customer orientation behaviour of the hotel employees. . In view of the managements' efforts toward achieving 'a' and 'b', 'd' and 'e' were hence hypothesized to show the mediating influence of personality and Job satisfaction of the hotel employees on the relationship between internal marketing and their customer orientation behaviour.

\section{Methodology}

This study examined effects of internal marketing on customer orientation behaviours of selected hotels' employees in Nigeria. Survey research design was adopted for the study. A total of 174 and 83 Hotel Guest Service Staff and Hotel Managers respectively were selected from 20 registered hotels operating in different parts of Nigeria. The selection of both hotels and the respondents used for study were done using convenience sampling method. Primary data were generated using two versions of selfdeveloped structured questionnaire tagged "Hotels' Internal Marketing Practices Questionnaire (HIMPQ)" and Hotel Employees Customer Orientation Questionnaire (HECOQ)”. HIMPQ was administered to hotel managers to get their responses on the independent variables (i.e Internal marketing practices) while HECOQ was used to get employees' responses on the dependent and moderating variables (i.e Customer orientation, personality traits and job satisfaction).

HIMPQ was divided into two sections, A and B. Section A contains demographic data of hotel managers while section $\mathrm{B}$ contains questions on the internal marketing variables measured by means of four major items and sub-items developed by Martel (2012). These four internal marketing variables are: Employees' empowerments, Employees' rewards and recognitions; Internal communications; and Training and development. The responses in section B of HIMPQ were on a 5-point Likert-type scale (1= strongly disagree to 5= strongly agree).

HECOQ which was administered to hotel employees was divided into four sections, A-D. Section A captured demographic data of employees. Section B, captured data on employees customer orientation behaviour variables adapted from Selling Orientation- Customer Orientation (SOCO) Scale developed by Saxe and Weitz (2010). The customer orientation variables adapted from SOCO scale were: Prompt attendance to customers' complaints, Assisting customers to assess their needs, Assisting customers to describe products and Avoiding the use of high pressure selling on customers. Section C contains data on personality variables measured by five 
major items developed by Bartone et al (2009). These are: Neuroticism, Extroversion, Openness, Agreeableness and Conscientiousness. Section D contains five major employees’ job satisfaction variables adapted from Job Description Index (JDI). These are: Pay, Promotion, Supervisor relationships, co-Worker relationships and Job contents. All items in section B of HECOQ were on a 5-point Likert-type scale (1= strongly disagree to 5= strongly agree)

Cronbach's Alpha test was used for ascertaining the reliability of the test instrument. The output of the test instruments indicated that the items on Hotel Employees Questionnaire and Hotel Managers Questionnaire were internally consistent at 0.87 and 0.81 coefficients respectively using Nunnally and Berustein's (1994) benchmark at 0.70 for assessing reliability results. The hypotheses were tested using multiple regression analysis.

\section{Data Analysis}

\section{Descriptive Analysis}

Out of the 174 copies of the questionnaire distributed to hotel employees, 132 (75.9\%) copies were returned while 67 (80.7\%) copies distributed to the hotel managers were returned and used for analysis.

Table 1: Respondents' Years of Service

\begin{tabular}{|c|c|c|c|c|}
\hline \multirow{2}{*}{ Year of Exp. in Hotel Job } & \multicolumn{2}{|c|}{ Managers } & \multicolumn{2}{c|}{ Hotel Employees } \\
\cline { 2 - 5 } & Freq. & $\mathbf{\%}$ & Freq. & \% \\
\hline$<5 y r s$ & 11 & 16.4 & 48 & 36.4 \\
\hline $5-9 y r s$ & 38 & 56.7 & 39 & 29.5 \\
\hline $10-14 \mathrm{yrs}$ & 16 & 23.9 & 27 & 20.5 \\
\hline$\geq 15 \mathrm{yrs}$ & 2 & 3.0 & 18 & 13.6 \\
\hline Total & 67 & 100.0 & 132 & 100.0 \\
\hline
\end{tabular}

Source: Field Survey, 2017

Table 1 above shows that out of the 67 managers who responded to our questions, 38 (56.7\%) have worked in their organizations between 5-9 years, $16(23.9 \%)$ have stayed between $10-14$ years, $11(16.4 \%)$ have less than 5 years working experience while only 2 (3.0\%) have stayed 15 years and above in their organizations. Similarly, out of 132 Hotel Employees, 48 (36.4\%) have less than 5 years working experience, 39 (29.5\%) have between 5-9 years of working experience; 27(20.5\%) have stayed between 10-14 years while 18 (13.6\%) have worked for 15 years and above. With the respondents' years of experience falling between 5-9 years, it can be deduced that a good number of them have relatively good working experience and can supply reliable data. 


\section{Test of Hypotheses \\ Hypothesis One}

$\mathrm{H}_{01}$ : Internal marketing does not have significant influence on customer orientation behavior

of hotel employees in Nigeria

$\mathrm{H}_{1}$ : Internal marketing has significant influence on customer orientation behavior of hotel employees in Nigeria.

Using multiple linear regression analysis method to test this hypothesis, the model below was used to represent the interaction between Customer Orientation (CO) Behavior of the Hotel Employees and the Internal Marketing Practices of the Hotel Managers.

$$
Y_{1}=\alpha+\beta_{a} X_{a}+\beta_{b} X_{b}+\beta_{c} X_{c}+\beta_{d} X_{d}+U
$$

Where $Y_{i}$ represents the dependent variable [i.e. Customer Orientation Behaviour of the Hotel Employees, $a_{i}$ represents the y-intercept [constant value] which explains the level of employees' customer orientation where internal marketing practices is zero [i.e. where no internal marketing is practiced]. $X_{a}, X_{b}, X_{c}$, and $X_{d}$ represent the independent variables [i.e. the Internal Marketing variables - internal communication; reward and recognition; training and development; and empowerment] while $\beta_{a}, \beta_{b}, \beta_{c}$, and $\beta_{d}$ represent the co-efficient of the independent variables. Each of these represents the percentage effect that each internal marketing variable has on the hotel employees' customer orientation behavior. $U$ represents the stochastic term that explains other unexplained variables that account for the customer orientation behavior of the Hotel Employees. The model can therefore be rewritten as thus;

$$
C O=\alpha+\beta_{a}[E m p]+\beta_{b}[R \& R]+\beta_{c}[I C]+\beta_{d}[T \& D]+U
$$

Emp represents Empowerment; $R \& R$ represents Reward and Recognition; IC represents Internal Communications and $T \& D$ represents Training and Development. The results of the analysis are presented below:

Table 2: Model Summary

\begin{tabular}{ccc}
\hline R square & 0.738444 & $73.8 \%$ \\
Adjusted R Square & 0.730206 & \\
S.E of the Estimate & 0.51202 & \\
F Change & 89.639 & \\
p-value & 0.000 & \\
\hline
\end{tabular}

Table 3: ANOVA

\begin{tabular}{ccccccc}
\hline & Model & Sum of Squares & Df & Mean Square & F & Sig. \\
\hline 1 & Regression & 4 & 94.00061 & 23.50015 & 89.63908 & $.000^{\mathrm{a}}$ \\
& Residual & 127 & 33.29485 & 0.262164 & & \\
\hline & Total & 131 & 127.2955 & & & \\
\hline
\end{tabular}

a. Predictors: (Constant), Empowerment, Reward and Recognition, Internal Communications, Training and Development

b. Dependent Variable: Customer Orientation 
Table 4: Coefficients

\begin{tabular}{ccccccc}
\hline & & \multicolumn{2}{c}{ Unstandardized Coeff } & Standardized Coeff & & \\
\cline { 3 - 5 } & Model & $\mathrm{B}$ & Std. Error & Beta & $\mathrm{t}$ & Sig. \\
\hline 1 & (Constant) & 0.0418 & 0.2299 & 0.0441 & 0.1817 & .000 \\
& Empowerment & 0.2909 & 0.0516 & 0.1711 & 5.6432 & .010 \\
& Reward \& Recog. & 0.7591 & 0.0698 & 0.6881 & 10.8784 & .003 \\
& Internal Comm. & 0.2358 & 0.0841 & 0.2422 & 0.2806 & .000 \\
& Training \& Dev. & 0.2948 & 0.0571 & 0.2767 & 0.5165 & .000 \\
\hline
\end{tabular}

a. Dependent Variable: Customer Orientation

The results of the regression analysis of the hypothesized interaction between customer orientation behavior of Employees and internal marketing practices of Hotel Managers were presented in Tables 2, 3 and 4 above. Table 2 above presents the model summary showing the coefficient of determination $\left[\mathrm{R}^{2}\right]$ which indicates that the model is fit at $\mathbf{7 3 . 8 \%}$. In affirmation of this, the result on Table 4 shows the explanatory effects of the coefficient. It can be deduced that each of the elements of internal marketing has a significant $(p<0.05)$ explanatory effect on customer orientation. The ANOVA test result on Table 3 further affirms the explanatory effect of the independent variables, indicating the overall significant $(\mathrm{F}=89.639, p<$ 0.05) effect of internal marketing practices of the Hotel Managers on the customer orientation behavior of the Employees.

Based on the foregoing results, the null hypothesis $\left[\mathrm{H}_{0}\right]$ which states that 'Internal marketing does not have significant influence on customer orientation behavior of hotel employees in Nigeria' would be rejected while the alternate hypothesis $\left[\mathrm{H}_{1}\right]$ would be accepted.

\section{Hypotheses two and three (Testing Moderating Effects)}

Hypotheses 2 and 3 were formulated to test the moderating influence of personality and job satisfaction on the relationship between internal marketing and customer orientation behavior of hotel employees. This nature of hypotheses has been tested in several extant similar studies but with diverse analytical techniques (Bellaouaied and Gam, 2012; Oakley and Carolina, 2012). However, in this study (Preacher and Hayes, 2004) method of testing mediation effect will be adopted.

In this current study, it is hypothesized that an internal marketing is sine qua non to employees' customer orientation but may however, be moderated by employees' personality [see Path 2 below] and employees' job satisfaction [see Path 3 below]. To address this hypothetical statement, the Preacher and Hayes (2004) approach establishes the likelihood of the moderation effect using the modeled path below for illustration. 
Path 1:

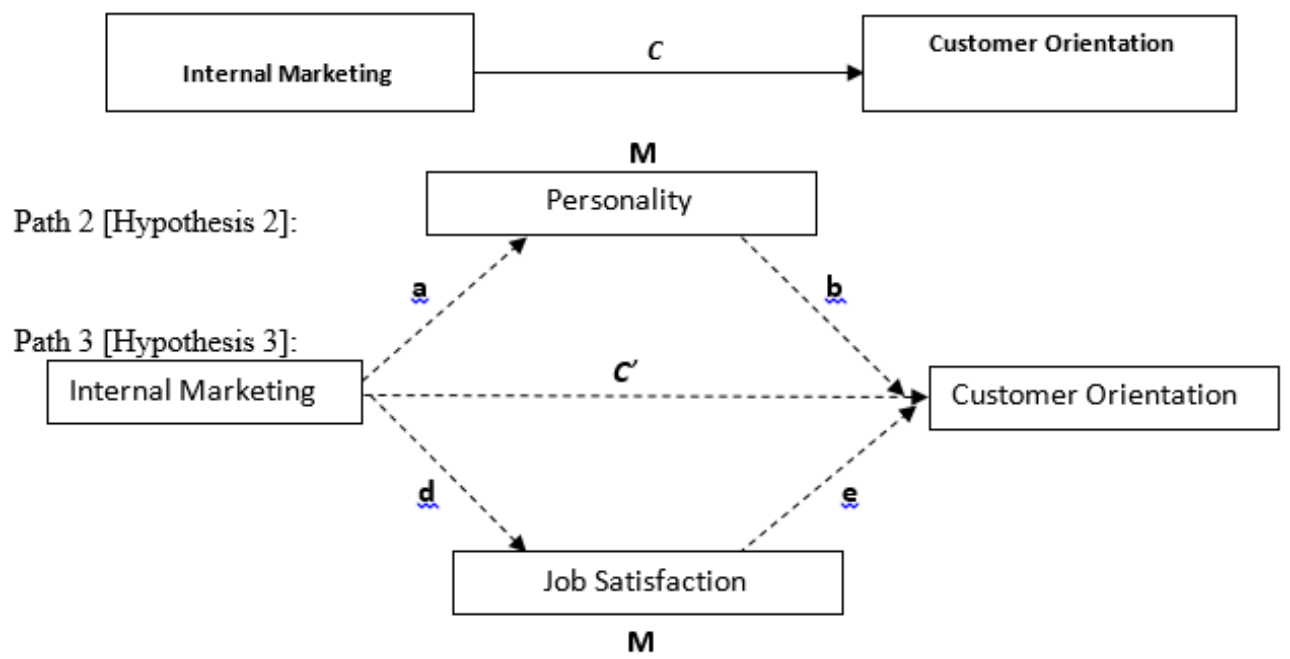

Path 1 above illustrates the situation establishing that there is a total effect (denoted by $\boldsymbol{C}$ ) between internal marketing and employees' customer orientation. Path 2 and 3 hence, illustrates where there is a moderated effect (denoted by $C^{\prime}$ ) between internal marketing and employees' customer orientation and that, it may be caused by employees' personality and employee job satisfaction constructs (denoted by $\boldsymbol{M}$ ). Preacher and Hayes (2004) argue that the presence of $\mathbf{M}$ would make the effect value of $\boldsymbol{C}^{\prime}$ between internal marketing practices and employees' customer orientation to become smaller compared to the total effect $\boldsymbol{C}$ when or where there is no $\mathbf{M}$ in Path 1 above.

This Preacher and Hayes' (2004) approach was hinged on some statistical assumptions which must first be certified. These include;

i. that Internal Marketing significantly predicts Hotel Employees'

Customer Orientation using a linear regression equation;

Customer Orientation $=\alpha_{i}+\boldsymbol{c}[$ Internal Markting $] \quad(\mathbf{c} \neq$ $0)$................Model 1

ii. that Internal Marketing significantly predicts $\mathbf{M}$ (i.e. Personality and Job Satisfaction) using the linear regression equation

For hyp 2: Personality $=\alpha_{i i}+\mathbf{a}[$ Internal Marketing $] \quad(\mathbf{a} \neq$ $0)$.....Model 2a

For hyp 3: Job Satisfaction $=\alpha_{i i i}+\mathbf{a}[$ Internal Marketing $](\mathbf{a} \neq$ $0)$........Model 2b

iii. that $\mathbf{M}$ (i.e. Personality and Job Satisfaction) significantly predicts Employees' Customer Orientation by controlling for Internal Marketing practices. 
For

hyp

2:Employee Customer Orientation $=$

$\alpha_{i v}+\boldsymbol{c}^{\prime}[$ Internal Marketing $]+$

$\boldsymbol{b}$ [Personality Factors]..........Model 3a

For hyp

Employee Customer Orientation $=$

$\alpha_{v}+\boldsymbol{c}^{\prime}[$ Internal Marketing $]+$

b [Job Satisfaction]...............Model 3b

\section{Hypothesis two}

$\mathrm{H}_{02}$ : Personality does not significantly moderate the relationship between internal marketing and the customer orientation behavior of the hotel employees

$\mathrm{H}_{2}$ : Personality significantly moderate the relationship between internal marketing and customer orientation behavior of the hotel employees

By adopting the above specified Preacher and Hayes (2004) approach, hypothesis two above was tested and the results are as follows.

Table 5: Model 1

\begin{tabular}{ccccccc}
\hline & & \multicolumn{2}{c}{ Unstand Coeff. } & Stand Coeff. & & \\
& Model & $\mathrm{B}$ & Std. Error & Beta & $\mathrm{t}$ & Sig. \\
\hline 1 & (Constant) & 2.405 & .301 & & 7.981 & .000 \\
& Internal Marketing & .430 & .075 & .451 & 5.766 & .000 \\
\hline
\end{tabular}

a. Dependent Variable: Customer Orientation

Table 6: Model 2a

\begin{tabular}{ccccccc}
\hline & Model & \multicolumn{2}{c}{ Unstand Coeff } & Stand Coeff & & \\
& & $\mathrm{B}$ & Std. Error & Beta & $\mathrm{t}$ & Sig. \\
\hline 1 & (Constant) & 3.511 & .261 & & 13.471 & .000 \\
& Internal Marketing & .179 & .065 & .236 & 2.772 & .006 \\
\hline
\end{tabular}

a. Dependent Variable: Personality

Table 7: Model 3a

\begin{tabular}{ccccccc}
\hline & & \multicolumn{2}{c}{ Unstand Coeff } & Stand Coeff & & \\
& & $\mathrm{B}$ & Std. Error & Beta & $\mathrm{t}$ & Sig. \\
\hline 1 & (Constant) & 1.982 & .437 & & 4.533 & .000 \\
& Personality & .493 & .102 & .392 & 4.858 & .000 \\
\hline 2 & (Constant) & 1.069 & .442 & & 2.418 & .017 \\
& Personality & .380 & .096 & .302 & 3.959 & .000 \\
& Internal Marketing & .362 & .073 & .380 & 4.975 & .000 \\
\hline
\end{tabular}

a. Dependent Variable: Customer Orientation

The results of the 3-step approach for testing the moderating influence of personality were presented on Tables 5, 6 and 7 above. Using the steps below to analyse the results; 


\section{Step 1:}

Internal Marketing significantly predicts Hotel Employees' Customer Orientation behaviour;

Customer Orientation $=2.405+\mathbf{0 . 4 3}[$ Internal Markting $] \quad(\mathbf{c} \neq$ $0)$.......Model 1

\section{Step 2:}

Internal Marketing significantly predicts $\mathbf{M}$ (Personality)

Personality $=3.511+\mathbf{0 . 1 7 9}[$ Internal Marketing $] \quad(\mathbf{a} \quad \neq$ $0)$.....Model 2a

\section{Step 3:}

M (i.e. Personality) significantly predicts Employees' Customer Orientation behaviour while controlling for Internal Marketing.

Hotel Employee Customer Orientation =

$1.982+\mathbf{0 . 3 6 2}[$ Internal Marketing $]+$

0. 38[Personality Factors].......Model 3a

Path 1: Direct

Effect
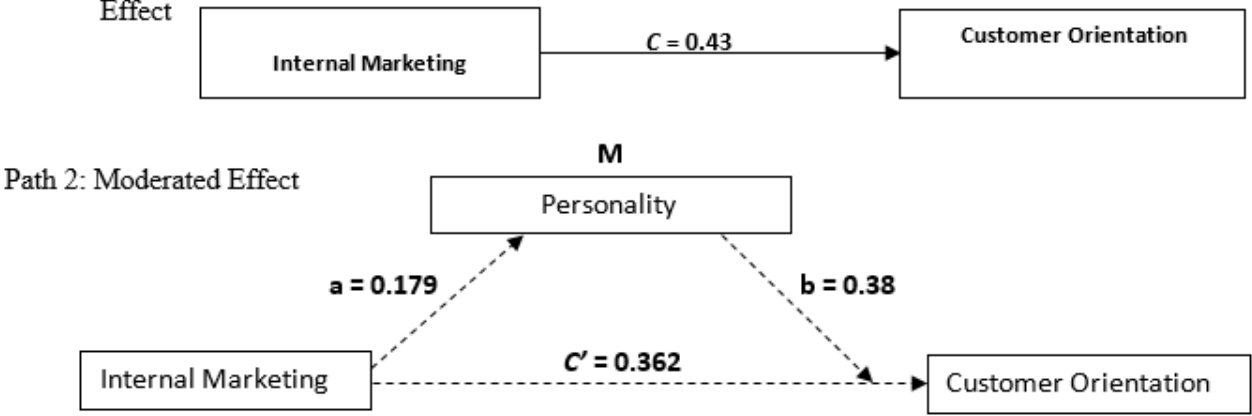

A careful analysis of the results and the paths presented above shows that, the Direct Effect ' $C$ ' between Internal Marketing of the Hotel Managers and the Customer Orientation behavior of the employees which was significant $(\boldsymbol{C}=\mathbf{0 . 4 3})$ at $5 \%$ level on Path 1 became moderated by the presence of the intervening variable 'Personality' on Path 2. The moderated effect $\left(\boldsymbol{C}^{\prime}=\mathbf{0 . 3 6 2}\right)$ was significant at $5 \%$ level of significance.

Based on this result, the null hypothesis $\left(\mathrm{H}_{02}\right)$ which states that Personality does not significantly moderate the relationship between internal marketing and customer orientation behavior of the employees would be rejected while the alternate hypothesis $\mathrm{H}_{2}$ was accepted.

\section{Hypothesis 3}

$\mathrm{H}_{05}$ : Job satisfaction does not significantly moderate the relationship between internal marketing and customer orientation behavior of the hotel employees 
$\mathrm{H}_{5}$ : Job satisfaction significantly moderates the relationship between internal marketing and customer orientation behavior of the hotel employees

Just as it was done in hypothesis two above, the 3-step approach for testing moderating effect was adopted for the above stated hypothesis too.

Table 8: Model 1

\begin{tabular}{ccccccc}
\hline & & \multicolumn{2}{c}{ Unstand Coeff. } & Stand Coeff. & & \\
& Model & $\mathrm{B}$ & Std. Error & Beta & $\mathrm{t}$ & Sig. \\
\hline 1 & (Constant) & 2.405 & .301 & & 7.981 & .000 \\
& Internal Marketing & .430 & .075 & .451 & 5.766 & .000 \\
\hline
\end{tabular}

a. Dependent Variable: Customer Orientation

Table 9: Model 2

\begin{tabular}{ccccccc}
\hline & Model & \multicolumn{2}{c}{ UnstandCoeff } & Standard Coeff & & \\
& & $\mathrm{B}$ & Std. Error & Beta & $\mathrm{t}$ & Sig. \\
\hline 1 & (Constant) & 3.383 & .213 & & 15.849 & .000 \\
& Internal Marketing & .226 & .053 & .352 & 4.283 & .000 \\
\hline
\end{tabular}

a. Dependent Variable: Job Satisfaction

Table 10: Model 3b

\begin{tabular}{ccccccc}
\hline & Model & \multicolumn{2}{c}{ Unstand Coeff } & Stand Coeff & & \\
& & $\mathrm{B}$ & Std. Error & Beta & $\mathrm{t}$ & Sig. \\
\hline 1 & (Constant) & -.412 & .396 & & -1.041 & .300 \\
& Job Satisfaction & 1.051 & .092 & .710 & 11.480 & .000 \\
\hline 2 & (Constant) & -.744 & .389 & & -1.910 & .058 \\
& Job Satisfaction & .931 & .093 & .629 & 9.961 & .000 \\
& Internal Marketing & .219 & .060 & .230 & 3.648 & .000 \\
\hline
\end{tabular}

a. Dependent Variable: Customer Orientation

The results of the 3-step approach for moderating influence test were presented through Tables 8, 9 and 10 above. Using the steps to analyze the results;

\section{Step 1:}

Internal Marketing significantly predicts Hotel Employees' Customer Orientation;

$$
\begin{aligned}
& \text { Customer Orientation }=2.405+\mathbf{0 . 4 3}[\text { Internal Marketing }](\mathbf{c} \neq \\
& 0) \ldots . . . \text { Model } 1
\end{aligned}
$$

\section{Step 2:}

Internal Marketing significantly predicts $\mathbf{M}$ (Job Satisfaction)

Job Satisfaction $=3.383+\mathbf{0 . 2 2 6}[$ Internal Marketing $] \quad(\mathbf{a} \quad \neq$ $0)$....Model $\mathbf{2 b}$

\section{Step 3:}

M (i.e. Job Satisfaction) significantly predicts Employees' Customer Orientation while controlling for Internal Marketing. 
Hotel Employee Customer Orientation $=$ $-0.744+0.219[$ Internal Marketing] + 0.931 [Job Satisfaction].......Model 3b

Path 1: Direct Effect
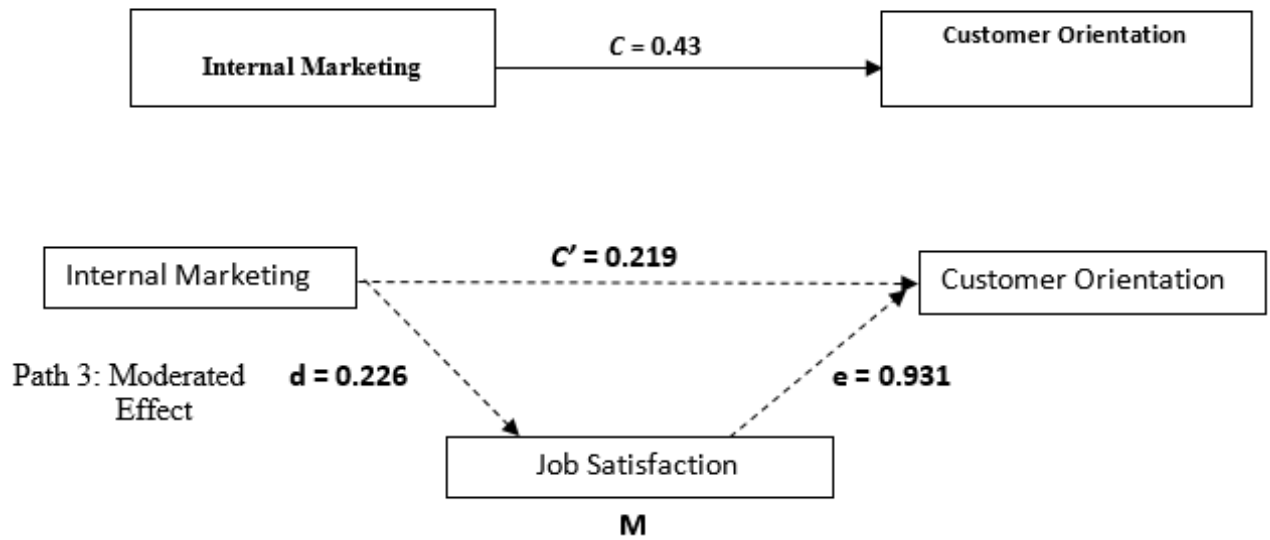

A careful analysis of the results and the paths presented above shows that, the Direct Effect ' $C$ ' between internal marketing of the Hotel Managers and the customer orientation behavior of the Hotel Employees which was significant $(\boldsymbol{C}=\mathbf{0 . 4 3})$ at $5 \%$ level on Path 1 became mediated by the presence of the moderating variable 'Job Satisfaction' on Path 3. The moderating effect $\left(C^{\prime}=\mathbf{0 . 2 1 9}\right)$ was significant at $5 \%$ level.

Based on this result, the null hypothesis $\left(\mathrm{H}_{03}\right)$ which states that $J o b$ satisfaction does not significantly moderate the relationship between internal marketing and customer orientation behavior of the hotel employees would be rejected while the alternate hypothesis $\mathrm{H}_{3}$ was accepted.

\section{Summary of Findings}

The study reveal that

i. Internal marketing has significant influence on customer orientation behavior of hotel employees in Nigeria.

ii. Personality significantly moderates the relationship between internal marketing and customer orientation behavior of the hotel employees in Nigeria.

iii. Job satisfaction significantly moderates the relationship between internal marketing and customer orientation behavior of the hotel employees in Nigeria.

\section{Conclusion}

The internal marketing practices of the Hotel Managers can assist more significantly in improving on customer orientation behaviours of the 
hotel employees. Poor customer services exhibited by employees in most hotels could be as a result of poorly -design internal marketing strategies. Most managers do not consider the personality of the employees they hire and this negatively affects the customer orientation behaviours of these employees. Job dissatisfaction is a possible reason for poor customer services rendered by the hotel employees in Nigeria.

\section{Recommendations}

Based on the findings of this study, it is recommended that;

i. The hotel managers should consider internal marketing practices a greater priority for achieving operational efficiency and customer service excellence.

ii. More so, the management of the hotels should give adequate focus on personality traist suitable for hotel service jobs such as neuroticism, extroversion, openness, agreeableness and conscientiousness when recruiting their hotel Guest Service Employees. This will enhance customer orientation behaviour of the employees. That deal directly with the customers.

iii. The hotel managers should also focus particularly on pay package, promotion opportunities, relationship with co-workers, relationship with supervisors, nature and content of the job to ensure that their staff are satisfied with their jobs as this will enhance internal marketing practices and customer orientation behaviour of the frontline staff and possibly the profitability of the firm.

\section{References:}

1. Awwad, M. S. and Agti, D. A. M. (2011). The impact of internal marketing on commercial banks' market orientation. International Journal of Bank Marketing. 29 (4), 308-332.

2. Bansal, H.S; Mendelson, M.; Sharma, B (2001). The impact of marketing activities on external marketing outcomes. Journal of Quality Management, 6, 61-76.

3. Bartone, P. T., Eid, J., Johnsen, B. H., Laberg, J. C. and Snook, S. A. (2009). Big five personality factors, hardiness, and social judgment as predictors of leader performance. Leadership \& Organization Development Journal. 30 (6), 498-521.

4. Bellaouaied, M., and Gam, A. (2012). Internal Marketing as a New Alternative for the Service Employees' Performance: An Empirical Study. Hal Archives-Ouvertes, 1-22.

5. Berry, L. L., Hensel, J. S., and Burke, M. C. (1976). Improving Retailer Capability for Effective Consumerism Response. Journal of Retailing, 52(3), 94-106. 
6. Brady, M. K. and Cronin, J. J. (2001). Customer orientation effects on customer service perceptions and outcome behaviors. Journal of Service Research. 3 (3), 241-251.

7. Broady-Preston, J. and Steel, L. (2002). Employees, customers and internal marketing strategies in LIS. Library Management. 23 (8/9), 384-393.

8. Churchill, G. A; Ford, N.M and Walker, O.C; Jr, (1997) "Sales Force Management", $5^{\text {th }}$ edition, U.S.A: Richard .D. Irwin.

9. Dalvi, M. R., and Vahidi, M. (2013). A Study of the Effects of Internal Marketing on Customer-oriented Social and Prosocial Behaviors (Case study: Hotels in Isfahan city). International Journal of Academic Research in Business and Social Sciences, 3(11), 253269.

10. Dunn, L. E. A., and Dahl, D. W. (2012). Self-Threat arid Product Failure: How Internal Attributions of Blame Affect Consumer Complaining Behavior. Journal of Marketing Research, XLIX(October), 670-681.

11. Farhad, R.; Ali, F. and Babak, J., (2013). Impact of Internal Marketing on Customer Royalty (Case Study: Iran Insurance Company-Kermanshah Province). International Research Journal of Applied and Basic Sciences. Vol. 4 (8). 2018-2025.

12. Greene, W. E.; Walla, D. G. and Schrest, L.J. (1994). Internal marketing: the key to exernal marketing success. The Journal of Services Marketing. 8 (4), 5-13.

13. Ha, N. C., Bakar, R. A. and Jaffar, S. I. S. (2007). Internal Marketing Issues in Service Organisations in Malaysia. International Review of Business Research Papers. 3 (5), 134-145.

14. Hennig-Thurau, T., and Thurau, C. (2003). Customer Orientation of Service Employees-Toward a Conceptual Framework of a Key Relationship Marketing Construct. Journal of Relationship Marketing, 2(1-2), 23-41.

15. Jenaibi, B. Al. (2010). Job Satisfaction: Comparisons Among Diverse Public Organizations in the UAE, 4(3), 60-79.

16. Kirca, A. H., Jayachandran, S. and Bearden, W. O. (2005). Market orientation: a meta-analytic review and assessment of its antecedents and impact on performance. Journal of marketing. 69 (2), 24-41.

17. Lings, I. N. and Greenley, G. E. (2005). Measuring internal market orientation. Journal of Service Research. 7 (3), 290-305.

18. Martel, E. (2012). Key Performance Indicators (KPIs)-How to enhance a company's bottom line. Marketing Canada. 
19. Neill, W. D. and Richard, J. E. (2012). Intranet portals: Marketing and managing individuals' acceptance and use. Australasian Marketing Journal (AMJ). 20 (2), 147-157.

20. Oakley, J. L., and Carolina, N. (2012). Bridging the Gap between Employees and Customers. Journal of Marketing Management, 28(910), 1094-1113.

21. Ogunnaike, O. O., Oyeniyi, O. and Adeniji, A. A. (2012). Internal Marketing Practices and Job Satisfaction: Evidence from a Nigerian University Setting. BRAND. Broad Research in Accounting, Negotiation, and Distribution. 3 (3), pp. 18-30.

22. Preacher, K. J., and Hayes, A. F. (2004). SPSS and SAS Procedures for Estimating Indirect Effects in Simple Mediation Models. Behaviour Research Methods, Instruments \& Computers, 36(4), 717731.

23. Rafiq, M. and Ahmed, P. K. (2000). Advances in the internal marketing concept: definition, synthesis and extension. Journal of services marketing. 14 (6), 449-462.

24. Ruizalba, J. L., Bermúdez-González, G., Rodríguez-Molina, M. A. and Blanca, M. J. (2014). Internal market orientation: An empirical research in hotel sector. International Journal of Hospitality Management. 38 (0), 11-19.

25. Saxe, R., and Weitz, B. A. (2010). The SOCO Scale: A Measure of the Orientation of Salespeople. Journal of Marketing Research, 19(3), 343-351.

26. Stock, J. H. and Watson, M. W. (2003). Introduction to econometrics, Addison Wesley Boston.

27. Tsui, A. S., Nifadkar, S. S., and Ou, A. Y. (2007). Cross-National, Cross-Cultural Organization Behaviour Research: Advances, Gaps and Recommendations. Journal of Management, 33(3), 426 - 478.

28. Vrontis, D., Thrassou, A., and Zin, R. M. (2010). Internal Marketing as an Agent of Change - Implennenting a New Human Resource Information System for Malaysian Airlines. Journal of General Management, 36(1), 21-42.

29. Wieseke, J., Ullrich, J., Christ, O. and Van Dick, R. (2007). Organizational identification as a determinant of customer orientation in service organizations. Marketing Letters. 18 (4), 265-278.

30. Yusuf, O., Inda, S., and Chin, A. T. (2014). The Effects of Internal Marketing on Customer Orientation in Nigerian Banking Industry. IOSR Journal of Business and Management, 16(11), 34-38. 